\title{
A NEW ADSORPTION AGENT FOR COAGULATION FACTORS
}

\author{
EY \\ JEAN-PIERRE SOULIER \\ From the Centre National de Transfusion Sanguine, 6, Rue Alexandre Cabanel, Paris, 15e
}

(RECEIVED FOR PUBLICATION APRIL 13, 1959)

Various bentonites constitute about $90 \%$ of montmorillonite, an ash of volcanic origin. The bentonites are essentially hydrated aluminium silicate crystallized into fine laminae, and are used in industry for filtration and clarification. We have been unable to find any reference in the literature to the use of bentonite in the adsorption of coagulation factors.

\section{Techniques}

"Prolabo" bentonite is a colourless powder, the composition of which is set out in Table $I$. The adsorption of plasma or serum was carried out at

TABLE I

COMPOSITION OF BENTONITE

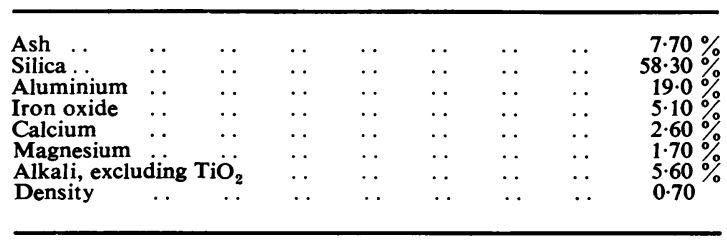

room temperature for exactly 10 minutes with constant gentle shaking. The methods for the assay of coagulation factors have been described elsewhere (Soulier and Larrieu, 1958).

\section{Results}

The adsorption of coagulation factors was studied in the presence of the following decalcifying agents: Ion exchange resins, ammonium citrate, ammonium oxalate, a mixture of potassium and ammonium oxalate, and sodium E.D.T.A. Whichever decalcifying technique was used, the results were similar and only the results using human citrated plasma ( 1 part of citrate $0.38 \%$ to 9 parts of blood) are reported here. Citrated plasma was exposed to different concentrations of bentonite and the concentration of the various coagulation factors was measured thereafter. The results of these various assays are reported in Table II. When a concentration of bentonite higher than $0.5 \%$ was used, it will be seen that the clotting time on recalcification and the Quick prothrombin time were all infinitely long. This suggests that fibrinogen had been adsorbed, a conclusion which was confirmed by the following

TABLE II

ABSORPTION BY BENTONITE FROM CITRATED PLASMA

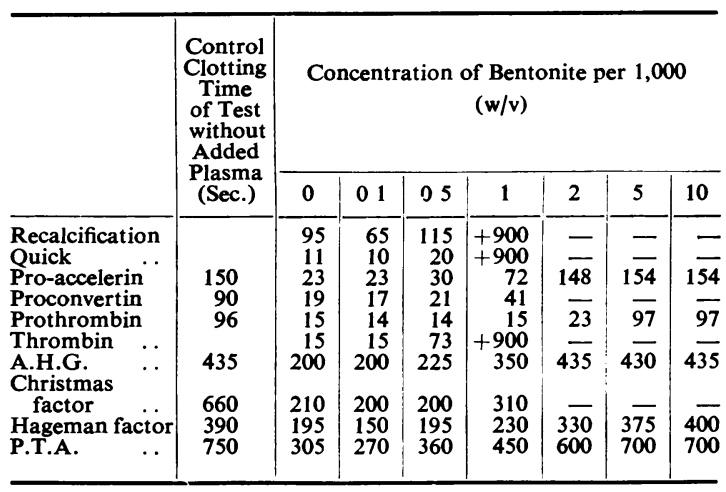

observations: no precipitate occurred on heating this plasma to $56^{\circ} \mathrm{C}$. for five minutes and electrophoresis of the adsorbed plasma showed no spot between the $\beta$ and $\gamma$ globulins. It will also be seen that antihaemophilic globulin (VIII) and pro-accelerin (V) were adsorbed when a concentration of about $1 \%$ bentonite was used. The factor VII complex (proconvertin and Stuart factor) and Christmas factor (IX) were adsorbed at a concentration of $2 \%$, while at this concentration only about 30 to $40 \%$ of true prothrombin was adsorbed. Finally, Hageman factor and P.T.A. were only adsorbed when $5 \%$ bentonite was used.

Other experiments not reported here substantiated the following points: (1) The adsorption of the various factors is equally satisfactory in the presence of citrate and oxalate and E.D.T.A. Adsorption is adequate in the absence of an anticoagulant (resin-treated plasma and serum). (2) The order and degree of adsorption of the different coagulation factors bv bentonite 
were constant for the same lot and for two different lots of bentonite obtained from the same firm. (3) Two successive adsorptions by $1 \%$ bentonite are little more efficacious than one exposure to $2 \%$ bentonite. (4) Heparin co-factor, antithrombin, and heparin were not adsorbed by the bentonite between the concentrations of 0.5 and $5 \%$. Plasminogen was more easily adsorbed than antiplasmin. The ionized calcium of plasma or serum was not adsorbed by $2 \%$ of the calcium salt of bentonite.

\section{Applications}

There are many uses for the adsorption technique with bentonite in the coagulation laboratory. In Fig. 1 the adsorptive power of bentonite on the various coagulation factors is represented diagrammatically, and reference to this will show how it is possible to separate fibrinogen from antihaemophilic factor and how prothrombin may be purified.

Separation of Fibrinogen and Antihaemophilic Globulin.-By using citrated or oxalate plasma or Cohn fraction 1 (E.D.T.A. plasma destroys antihaemophilic globulin) and bentonite $0.5 \%$, it is possible to obtain antihaemophilic globulin separated from fibrinogen. Results of this differential adsorption are illustrated in Tables III and IV. It will be seen that bentonite is superior to Fuller's earth, since Wagner, Richardson, and

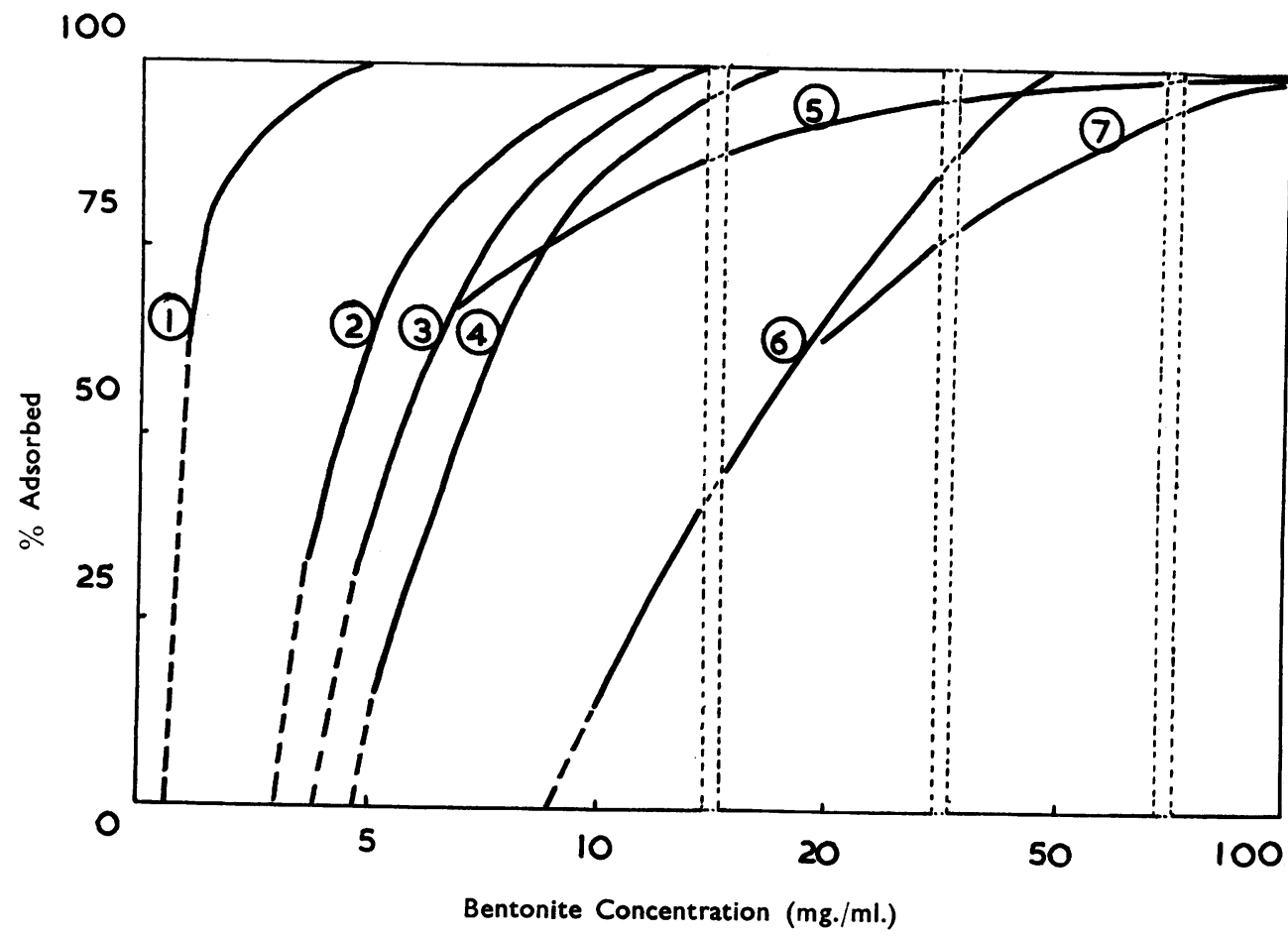

(1) Fibrinogen

(2) Pro-accelerin

(3) Antihaemophilic globulin

(4) Proconvertin, Stuart, and Christmas factors 
TABLE III

SEPARATION OF A.H.G. FROM FIBRINOGEN IN CITRATED PLASMA

\begin{tabular}{c|c|c|c|c}
\hline & \multicolumn{2}{|c|}{ Fibrinogen } & \multicolumn{2}{c}{$\begin{array}{c}\text { Antihaemophilic } \\
\text { Globulin }\end{array}$} \\
$\begin{array}{c}\text { Bentonite } \\
\text { (mg./ml.) }\end{array}$ & $\begin{array}{c}\text { Thrombin } \\
\text { Clotting } \\
\text { Time (Sec.) }\end{array}$ & $\begin{array}{c}\text { Percentage } \\
\text { of } \\
\text { Normal }\end{array}$ & $\begin{array}{c}\text { One-stage } \\
\text { Ostimation } \\
(\text { Sec.) }\end{array}$ & $\begin{array}{c}\text { Percentage } \\
\text { of } \\
\text { Normal }\end{array}$ \\
\hline 0 & 14 & 100 & 215 & 100 \\
1 & 17 & 30 & 215 & 100 \\
3 & 22 & 18 & 215 & 100 \\
4 & 40 & 12 & 220 & 60 \\
7 & +600 & $0-10$ & 225 & 50 \\
9 & & 0 & 230 & 45 \\
& & 0 & 240 & 40 \\
\hline
\end{tabular}

* Control time in absence of A.H.G.: $600 \mathrm{sec}$.

TABLE IV

SEPARATION BY BENTONITE OF A.H.G. IN COHN'S FRACTION 1 (PROTEIN CONCENTRATION 0.4\%) FROM FIBRINOGEN

\begin{tabular}{c|c|c|c|c}
\hline & \multicolumn{2}{|c|}{ Fibrinogen } & \multicolumn{2}{c}{$\begin{array}{c}\text { Antihaemophilic } \\
\text { Globulin }\end{array}$} \\
$\begin{array}{c}\text { Bentonite } \\
\text { (mg./ml.) }\end{array}$ & $\begin{array}{c}\text { Thrombin } \\
\text { Clotting } \\
\text { Time (Sec.) }\end{array}$ & $\begin{array}{c}\text { Percentage } \\
\text { Remaining }\end{array}$ & $\begin{array}{c}\text { One-stage } \\
\text { Estimation } \\
(\text { Sec.) }\end{array}$ & $\begin{array}{c}\text { Percentage } \\
\text { Remaining }\end{array}$ \\
\hline 0 & 14 & 100 & 235 & 100 \\
3 & 50 & 11 & 235 & 100 \\
4 & +200 & 0 & 305 & 28 \\
5 & +200 & 0 & 315 & 22 \\
6 & +200 & 0 & 450 & 7 \\
\hline
\end{tabular}

* Control time in absence of A.H.G. $=540 \mathrm{sec}$.

Brinkhous (1957) claim that 20 times more Fuller's earth is required to adsorb human fibrinogen. Bentonite was used at the same concentration as aluminium hydroxide, but has the advantage that it does not have to be prepared specially and that the results are highly reproducible. Using bentonite we have been able to prepare a sample of human antihaemophilic globulin, free of fibrinogen, which was 70 times more active than fresh human plasma as judged by the weight of protein.

Purification of Prothrombin.-Bentonite used at a concentration of $2 \%$ produced the following effects: Fibrinogen, antihaemophilic globulin, Christmas factor, and proconvertin were removed, while prothrombin and a part of factors P.T.A. and Hageman were left. To isolate prothrombin treated plasma was further adsorbed selectively with tricalcium phosphate (Baker) $0.5 \% .^{*}$ We have been able to obtain several samples of purified prothrombin by this method which contained trace quantities of factor VII and Christmas factor too small to be measured: even the prothrombin

*P. Didisheim, working in this laboratory, has shown that Baker's tricalcium phosphate is by far the most active of all the adsorbents of the prothrombin complex and Christmas factor.
TABLE V

PURIFICATION OF PROTHROMBIN IN OXALATED $(0.15 \%)$ PLASMA

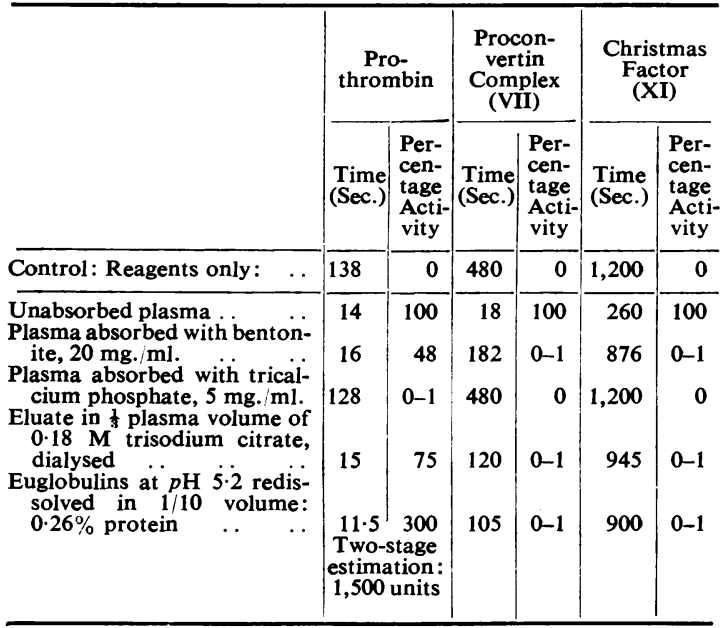

prepared by Seegers (1952) is not completely free of these two factors. Table $\mathrm{V}$ records an example of some actual results obtained. By this method it is possible reproducibly to obtain purified prothrombin concentrated (600 units/mg.) and with a high yield. There seems to be no reason why a higher concentration should not be obtained. Electrophoresis on starch block shows that this fraction produces a single band in the $\alpha_{2}$ globulin position.

\section{Bentonite and the Contact Factor}

The contacting activity of bentonite on normal citrated plasma, using the low concentration of $1 \mathrm{mg} . / \mathrm{ml}$. which does not adsorb coagulation factors, has been studied and compared with that of kaolin, which has been studied extensively by Margolis (1957). All tests were carried out in silicone-treated tubes and the results are

TABLE VI

ACTIVATION OF CITRATED PLASMA BY BENTONITE OR KAOLIN

\begin{tabular}{l|c|c|c|c}
\hline & $\begin{array}{c}\text { Clotting } \\
\text { Time of Test } \\
\text { without } \\
\text { Added } \\
\text { Plasma }\end{array}$ & $\begin{array}{c}\text { Untreated } \\
\text { Plasma } \\
\text { (Sec.) }\end{array}$ & $\begin{array}{c}\text { Plasma } \\
\text { Exposed to } \\
\text { 1 mg. Ben- } \\
\text { tonite per } \\
\text { ml. (Sec.) }\end{array}$ & $\begin{array}{c}\text { Plasma } \\
\text { Exposed to } \\
\text { 1 mg. Kao- } \\
\text { lin per ml. } \\
\text { (Sec.) }\end{array}$ \\
\hline Recalcification & & 125 & 105 & 125 \\
Quick & 14 & 13 & 13 \\
Pro-accelerin .. & 75 & 30 & 28 & 27 \\
Proconvertin .. & +240 & 29 & 25 & 28 \\
Prothrombin .. & 72 & 18 & 18 & 18 \\
A.H.G. & +600 & 330 & 200 & 270 \\
Christmas factor & +600 & 260 & 165 & 180 \\
Hageman factor & 525 & 330 & 195 & 200 \\
P.T.A. & 660 & 310 & 220 & 220 \\
\hline
\end{tabular}


summarized in Table VI. It will be seen that bentonite apparently activates the contact factor to a greater degree than an equal weight of kaolin, and activation is shown by the shortening of the recalcification and Quick times. It diminishes the apparent concentration of factor VII, P.T.A., and Christmas factor, and it interferes to some extent with the estimation of antihaemophilic globulin. (These findings are reported in full in another paper devoted to a further study of the contact factor.)

\section{Stabilization of Plasma by Heat}

Citrated plasma treated with $5 \%$ bentonite, or with 0.5 to $1 \%$ in the presence of mandelate (a stabilizing anion used during heat treatment of the albumin fraction), will not gel when heated to $60^{\circ} \mathrm{C}$. for several hours. Thus it is possible to use this simple procedure to stabilize plasma before the heat treatment required to destroy the virus of infective hepatitis. The more complex treatments proposed (Nitschmann, Kistler, Renfer, Hässig, and Joss, 1956) are then unnecessary.

\section{Summary}

Bentonite is an adsorbent of coagulation factors. It adsorbs fibrinogen at a concentration of $0.5 \%$ and fibrinogen can thus be removed from plasma or from plasma fractions containing antihaemophilic globulin. True prothrombin can be separated from the other coagulation factors normally present in prothrombin preparations. Bentonite $0.1 \%$ is an even greater activator of the "contact factor" than kaolin. Five per cent. bentonite prevents the gelling of plasma at $60^{\circ} \mathrm{C}$

We wish to thank Mlle. Weilland and Mme. ProuWartelle for their excel'ent technical assistance. We also wish to thank Dr. J. R. O'Brien for his kindness in translating this paper.

\section{REFERENCES}

Margolis, J. (1957). J. Physiol. (Lond.), 137, 95

Nitschmann, H., Kistler, P., Renfer, H. R., Hässig, A., and Joss, A. (1956). Vox Sang. (Basel), n.s., 1, 183.

Seegers, W. H. (1952). Rec. Chemic. Progress, 13, 143.

Soulier, J. P., (1959). Rev. Hémat., 14, 26.

Rev. Hemat.

and Larrieu, M. J. (1958). Hémostase. Théorie. Tests. In Encyclopédie Médico-Chirurgicale. Vol. Transfusion Sanguine. Wagner, R. H., Richardson, B. A., and Brinkhous, K. M. (1957). Thromb. Diath. haem., 1, 